\title{
Lung cancer underlying paravertebral abscess with intramedullary spinal cord metastases
}

\author{
Laura Iliescu, Letitia Toma
}

Department of Internal Medicine, Fundeni Clinical Institute, Bucharest, Romania

\section{Correspondence to} Dr Laura lliescu, laura_ate@yahoo.com

\section{DESCRIPTION}

A 59-year-old patient presented with a 2-month history of increasing backache irradiating in the abdomen. All standard laboratory tests results were within the normal limits, with the exception of a moderate inflammatory syndrome. Lower limb paralysis occurred soon after admission. A neurological examination revealed a complete loss of motor function.

An MRI displayed the pathological compressive fractures of the T1, T6, T11, T12 vertebral bodies and the total damage of the T7-T8 vertebrae, with total destruction of the T7 vertebral body and vertebrae compaction (figure 1).

The MRI also displayed a large expansive soft tissue mass, located at the costovertebral joints T7T8 (figure 2).
The CT scan displayed a large necrotic mass on the right side, which completely penetrated the bone cortex and invaded the T7-T8 vertebral bodies; it highlighted a massive pleural effusion on the left side (figure 3 ).

The patient died within $2 \mathrm{~h}$ after the examination.

Despite the fact that the patient showed relatively common symptoms, his condition deteriorated rapidly after admission.

Initially the lower limb paralysis required performing an MRI exam, the suspected diagnosis being the pathological compressive fracture.

The large soft tissue mass expanding from the lung motivated us to perform a CT scan.

It is essential to be aware of the different manifestations of spinal metastatic disease, as the spine is the most common site of osseous metastatic disease. ${ }^{12}$

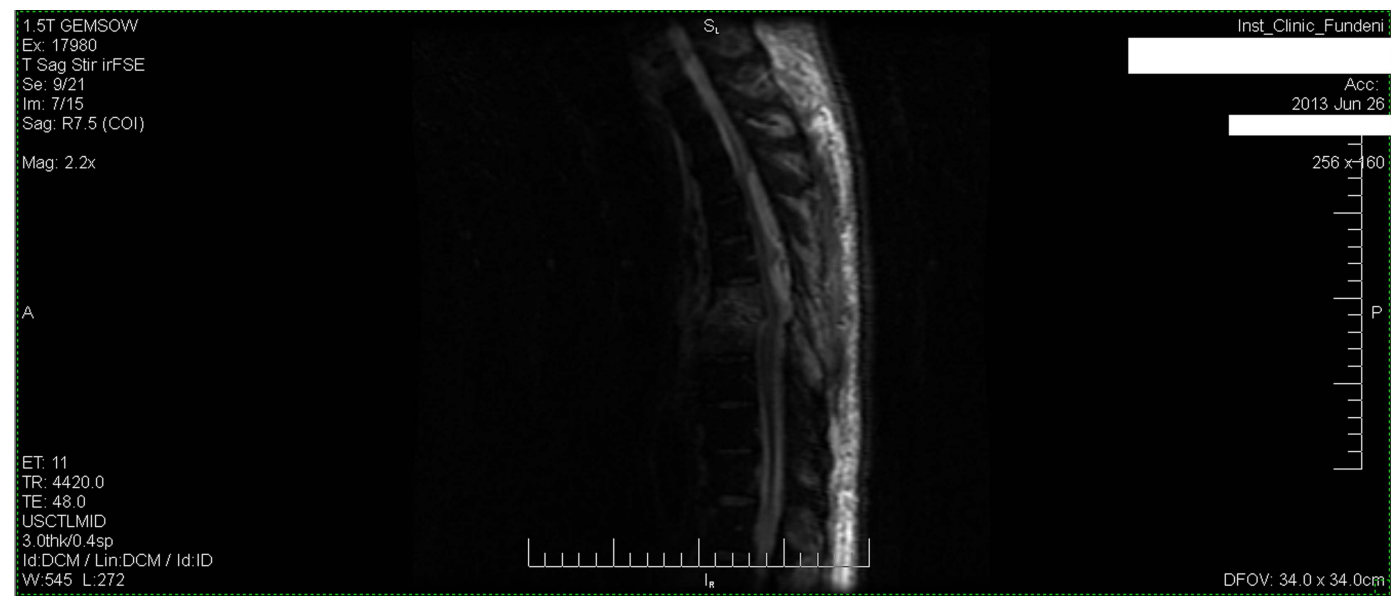

Figure 1 MRI sequence of pathological compressive fractures of T1, T6, T11, T12 vertebral bodies and the total damage of the T7-T8 vertebrae, with total destruction of T7 vertebral body and vertebrae compaction.

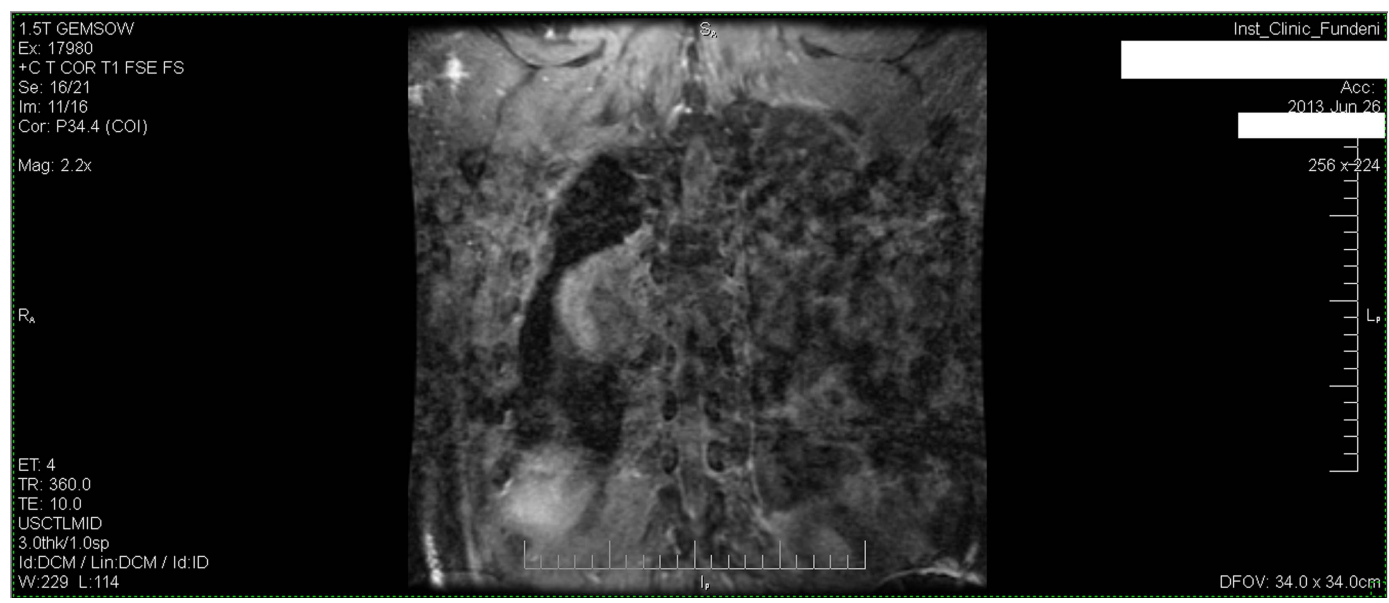

Figure 2 MRI sequence of large expansive soft tissue mass, located at the costovertebral joints T7-T8.
To cite: lliescu L, Toma L. BMJ Case Rep Published online: [please include Day Month Year] doi:10.1136/ bcr-2013-201070 


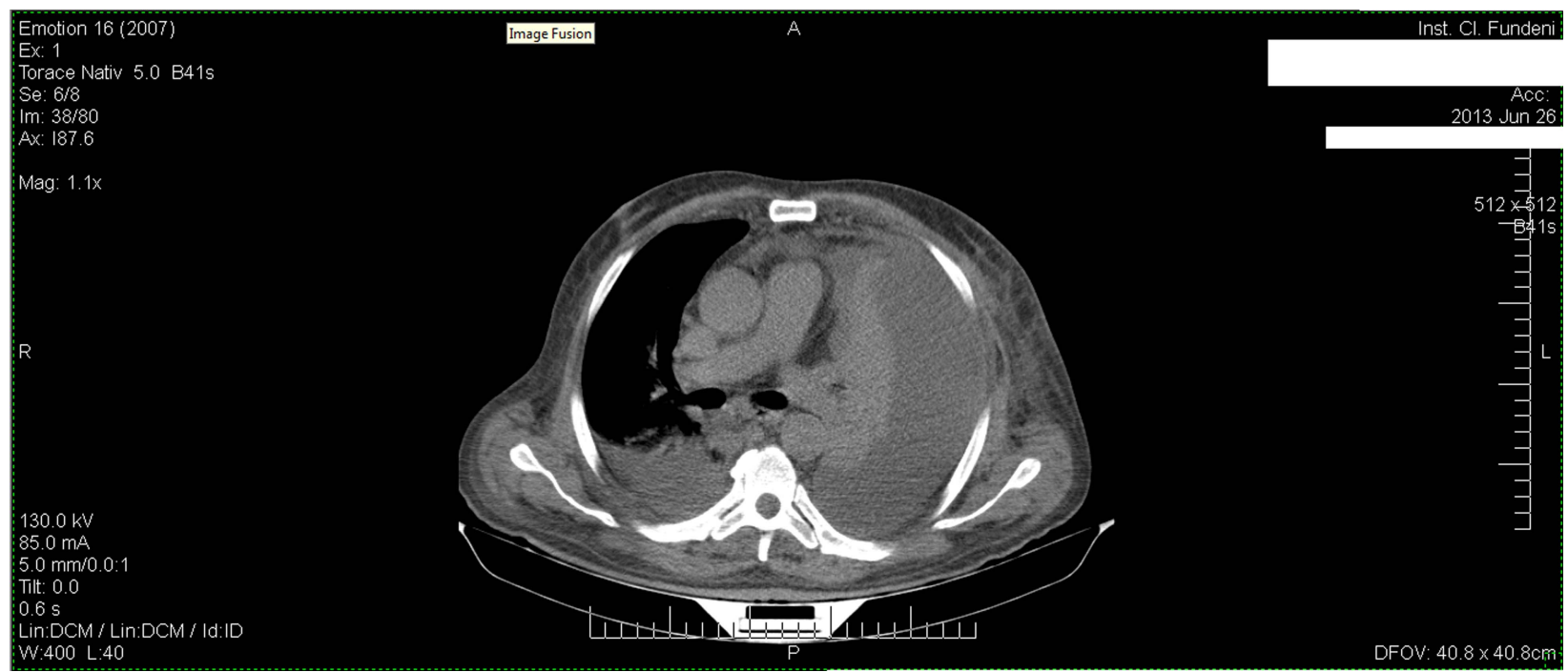

Figure 3 CT scan displaying large necrotic mass on the right side, which completely penetrated the bone cortex and invaded the T7-T8 vertebral bodies and a massive pleural effusion on the left side.

Imaging techniques play a fundamental role in diagnosis and treatment planning in spinal malignancies. ${ }^{3}$

\section{Learning points}

- The cause of a backache is almost impossible to define and only a small percentage of patients have an identifiable underlying cause. A comprehensive history, a physical examination and especially a high-resolution image technique can identify the small percentage of patients with serious conditions that require immediate further evaluation and therapy. These conditions include infections, malignancies and neurological disorders. The possibility of a referred pain from other organs should also be considered.

- Malignant tumours aggravated by abscess tend to develop quickly and ultimately are fatal.

- With proper technique and interpretation skills, the overwhelming majority of compressive fractures can be accurately differentiated by using routine MRI sequences.
Competing interests None.

Patient consent Obtained.

Provenance and peer review Not commissioned; externally peer reviewed.

\section{REFERENCES}

1 Wilson MA, Calhoun FM. The distribution of skeletal metastases in breast and pulmonary cancer: concise communication. J Nucl Med 1981;22:594-7.

2 Tofe AJ, Francis MD, Harvey WJ. Correlation of neoplasms with incidence and localization of skeletal metastases: an analysis of 1,355 diphosphonate bone scans. J Nucl Med 1975;16:986-9.

3 Scutellari PN, Antinolfi G, Galeotti R, et al. Metastatic bone disease. Strategies for imaging. Minerva Med 2003;94:77-90.

Copyright 2013 BMJ Publishing Group. All rights reserved. For permission to reuse any of this content visit http://group.bmj.com/group/rights-licensing/permissions.

BMJ Case Report Fellows may re-use this article for personal use and teaching without any further permission.

Become a Fellow of BMJ Case Reports today and you can:

- Submit as many cases as you like

- Enjoy fast sympathetic peer review and rapid publication of accepted articles

- Access all the published articles

- Re-use any of the published material for personal use and teaching without further permission

For information on Institutional Fellowships contact consortiasales@bmjgroup.com

Visit casereports.bmj.com for more articles like this and to become a Fellow 